\title{
CHEMICAL DISPERSANTS AND PRE-TREATMENTS TO DETERMINE CLAY IN SOILS WITH DIFFERENT MINERALOGY(1)
}

\author{
Cristiane Rodrigues ${ }^{(2)}$, Virlei Álvaro de Oliveira ${ }^{(3)}$, Pedro Marques \\ da Silveira ${ }^{(4)} \&$ Glenio Guimarães $\operatorname{Santos}^{(5)}$
}

\begin{abstract}
Knowledge of the soil physical properties, including the clay content, is of utmost importance for agriculture. The behavior of apparently similar soils can differ in intrinsic characteristics determined by different formation processes and nature of the parent material. The purpose of this study was to assess the efficacy of separate or combined pre-treatments, dispersion methods and chemical dispersant agents to determine clay in some soil classes, selected according to their mineralogy. Two Brazilian Oxisols, two Alfisols and one Mollisol with contrasting mineralogy were selected. Different treatments were applied: chemical substances as dispersants (lithium hydroxide, sodium hydroxide, and hexametaphosphate); pre-treatment with dithionite, ammonium oxalate, and hydrogen peroxide to eliminate organic matter; and coarse sand as abrasive and ultrasound, to test their mechanical action. The conclusion was drawn that different treatments must be applied to determine clay, in view of the soil mineralogy. Lithium hydroxide was not efficient to disperse low-CEC electropositive soils and very efficient in dispersing high-CEC electronegative soils. The use of coarse sand as an abrasive increased the clay content of all soils and in all treatments in which dispersion occurred, with or without the use of chemical dispersants. The efficiency of coarse sand is not the same for all soil classes.
\end{abstract}

Index terms: chemical agents, soil classes, diagnostic horizon, analysis methodology, soil particles, soil profile.

\footnotetext{
(1) Part of the Master's thesis of the first author, at the Federal University of Goiás, UFG - Subject area: Soil and Water. Received for publication in September 16, 2010 approved in July 7, 2011.

(2) Master in Agronomy, Solocria Laboratório Agropecuário. Avenida Goiás 5106, Setor Urias Magalhães, CEP 74565-250 Goiânia (GO). E-mail: crissolocria@yahoo.com.br

(3) Doctor in Geosciences. Fundação IBGE, Unidade Estadual de Goiás, Goiânia (GO). E-mail: virlei@ibge.gov.br

(4) Researcher for Embrapa Arroz e Feijão. Rodovia GO-462, km 12, Zona Rural, Caixa Postal 179, CEP 75375-000 Santo Antônio de Goiás (GO). E-mail: pmarques@cnpaf.embrapa.br

(5) Full Professor at the Federal University of Piauí - UFPI. Campus Professora Cinobelina Elvas. BR 135 km 3, CEP 64900000 Bom Jesus (PI). E-mail: gleniogm@gmail.com
} 


\title{
RESUMO: DISPERSANTES QUÍMICOS E PRÉ-TRATAMENTOS NA AVALIAÇÃO DO TEOR DE ARGILA DE SOLOS DE DIFERENTES MINERALOGIAS
}

\begin{abstract}
O conhecimento das propriedades físicas do solo, incluindo os teores de argila, é de suma importância para a agricultura. Solos aparentemente iguais podem apresentar comportamento diferente devido a características intrínsecas, determinadas pela atuação de processos de formação diferentes e pela natureza de seu material formador. Este trabalho objetivou avaliar pré-tratamentos, métodos de dispersão e agentes químicos dispersantes, isoladamente ou de forma combinada, na determinação dos teores de argila de algumas classes de solos selecionadas com base na sua natureza mineralógica. Foram selecionados cinco (mas estão citados apenas 4) solos de natureza mineralógica contrastante: Latossolos Acriférricos (oxídicos), Argissolo e Nitossolo (cauliníticos) e Chernossolo (esmectítico). Foram utilizados tratamentos distintos: substâncias químicas como dispersantes, (hidróxido de sódio, hidróxido de lítio e hexametafosfato); pré-tratamentos com ditionito, oxalato de amônio e água oxigenada, para eliminação de matéria orgânica; como ações mecânicas, foi testado o uso de areia grossa como abrasivo e do ultrassom. Os resultados permitiram a conclusão de que: há a necessidade de que sejam dados tratamentos diferenciados na determinação de argila, levando-se em consideração a natureza mineralógica do solo; o hidróxido de lítio não é eficiente para dispersar solos eletropositivos com baixa CTC, mas muito eficiente na dispersão de solos eletronegativos com elevada CTC; o uso de areia grossa como abrasivo aumentou os niveis de argila em todos os tratamentos em que aconteceu a dispersão para todos os solos, com e sem o uso de dispersante químico; e a utilização de areia grossa não tem eficácia igual em todas as classes de solo.
\end{abstract}

Termos de indexação: agentes químicos, classes de solo, horizonte diagnóstico, metodologia de análise, partículas do solo, perfil do solo.

\section{INTRODUCTION}

Although seemingly simple, the determination of the soil particle size is one of the most problematic areas in pedology. Differences in laboratory results are still common and substantial, which reinforces the need that field data should be collected very carefully by the surveyors. These differences have been associated to difficulties in dispersing the sampled material, due to calcareous or saline nature, or high organic matter content (> 5\%) of the soil. In these cases, special treatments are required to avoid interferences with soil analyses (Oliveira, 2007).

According to Day (1965), the soil is dispersed by a combination of chemical and mechanical methods; the former are based on the concept of colloidal particle repulsion, while the physical or mechanical methods involve the separation of individual particles by processes such as sample friction, shaking and vibration.

Chemical dispersion is essentially based on the increase in particle repulsion in response to an increase in zeta potential. The process is normally based on the saturation of the exchange complex with a highly electronegative cation, resulting in a large hydrated radius. Between these cations, the dispersion efficiency scale is, according to Baver (1972): $\mathrm{Li}>\mathrm{Na}$ $>\mathrm{K}=\mathrm{NH}_{4}>\mathrm{Rb}>\mathrm{Cs}$. Chemical compounds containing $\mathrm{Na}^{+}$are used most often, as they are easily purchasable and cheap, although this cation is not the most dispersion-efficient.

Mechanical dispersion using cocktail shakers is the most common method in the routine of most soilphysics laboratories, given the ease and speed of the process. Oliveira et al. (2002) compared several mechanical dispersion methods associated to chemical treatments; they concluded that the slow mechanical agitation method, using horizontal shaking in helicoidal motion for $3 \mathrm{~h}$ and adding $30 \mathrm{~g}$ of coarse sand as an abrasive, was more efficient in dispersing particles of gibbsite-rich Oxisols than the cocktail shaker method, which resulted in values closer to the ultrasonic dispersion method used as control.

Ultrasonic dispersion is based on the principle of vibration wave transmission in the soil solution. Genrich \& Bremner (1972) and Grohmann (1975) observed that the use of ultrasonic dispersion is restricted to research work, given its low productivity and/or higher equipment cost. The use of coarse sand particles, steel balls, glass balls and other materials as "abrasives" is a common practice in Brazilian laboratories, with a view to an increased efficiency in dispersing oxidic soils. This procedure is not officially recommended in technical manuals but has been widely used because it is believed to be efficient in the dispersion of such soils.

No method should be applied as a standard practice, but for each soil or soil class the method 
should be chosen with best dispersion, lowest number of procedures and highest cost-effectiveness according to the respective activity, bearing in mind that dispersion is a complex process involving variables such as shaking, the presence of abrasive agents and dispersing agents (Carvalho, 1985). High clay-content clusters are not always completely separated by chemical and mechanical dispersion, resulting in an overestimated silt fraction in soil analysis (Donagemma et al., 2003). Success in soil particlesize analysis depends on the establishment of soil suspensions in which the particles are and remain effectively individualized, until their separation and quantification (Medina \& Grohmann, 1962). Intense mechanical dispersion or methods using ultrasound combined with appropriate chemical pre-treatments will produce results with higher clay yields. In contrast, a less drastic dispersion, be it chemical or mechanical, may result in a more natural distribution of soil particles (Gee \& Bauder, 1986).

Most laboratories use pre-treatments rather seldom in routine analyses, but apply them to remove cementing and flocculating agents (especially organic matter), iron oxides, carbonates and soluble salts (Gee \& Bauder, 1986). Pre-treatment methods may produce differing results and thus the operation for soil particle-size analysis must be clearly defined, as results will depend on the method adopted (Mckeauge, 1978). Santana (1973), Menk \& Oliveira (1974) and Barreto (1986) noted substantial increases in the clay proportion of Oxisol class soils with the application of pre-treatments.

This study aimed to assess pre-treatments, dispersion methods and chemical dispersing agents, isolated or combined, in the determination of the clay content of some soils chosen according to their mineralogy.

\section{MATERIAL AND METHODS}

Samples of the diagnostic B horizon of five soil profiles with differing mineralogical compositions were used in this study. The profiles were chosen with a view to analyzing soils with dispersion problems, e.g, the oxidic Oxisols of Central Brazil, as well as soils with a distinct mineralogy, but important from a geographical or economic viewpoint. The chosen profiles (properties listed in Tables 1 and 2) were classified according to Embrapa (2006) in the following order: profile 1 (P.1) - Argissolo Vermelho Amarelo Eutrófico típico (Ouro Verde, GO), profile 2 (P.2) Chernossolo Argilúvico órtico típico (Ipiaú, BA), profile 3 (P.3) - Latossolo Vermelho Acriférrico típico (Ouro Verde, GO), profile 4 (P.4) - Latossolo Vermelho Acriférrico típico (Jataí, GO) and profile 5 (P.5) Nitossolo Vermelho Eutroférrico típico (Ceres, GO).

The samples were collected as recommended by the Manual Técnico de Pedologia (Oliveira, 2007). From the five profiles studied, a total set of 20 samples was collected from each genetic horizon (four per sampled profile), for the double purpose of taxonomic characterization and the specific objectives of this study.

The soil samples were analyzed in the laboratory Solocria, in Goiânia (GO), the soil physics laboratory of the Federal University of Lavras (MG) and the laboratory of Furnas Centrais Elétricas S.A, in Aparecida de Goiânia (GO). Several procedures to induce clay dispersion were tested, based on the various procedures and resources of physical or mechanical as well as chemical nature, and even on the combination of these procedures, totaling 13 treatments.

For treatment 1 (T.1), clay dispersion was performed with $10 \mathrm{~g}$ of oven-dried fine soil, using

Table 1. Mean values of chemical and mineralogical properties of the soil samples in horizon B

\begin{tabular}{|c|c|c|c|c|c|}
\hline \multirow{2}{*}{ Element } & \multicolumn{5}{|c|}{ Soil profile } \\
\hline & P.1-PVAe & P.2-MTo & P.3-LVwf & P.4-LVwf & P.5-NVef \\
\hline & \multicolumn{5}{|c|}{ Horizon } \\
\hline & $\mathrm{Bt}_{2}$ & $\mathrm{Bt}_{2}$ & $\mathrm{Bw}_{2}$ & $\mathrm{Bw}_{2}$ & $\mathrm{Bt}_{2}$ \\
\hline $\mathrm{S}\left(\mathrm{cmol}_{\mathrm{c}} \mathrm{dm}^{-3}\right)$ & 8.53 & 50.99 & 0.35 & 0.35 & 7.27 \\
\hline $\mathrm{T}\left(\mathrm{cmol}_{\mathrm{c}} \mathrm{dm}^{-3}\right)$ & 11.43 & 52.89 & 3.15 & 3.65 & 9.27 \\
\hline $\mathrm{V}(\%)$ & 74.64 & 96.41 & 11.05 & 9.59 & 78.43 \\
\hline $\mathrm{pH}\left(\mathrm{H}_{2} \mathrm{O}\right)$ & 6.6 & 6.5 & 5.0 & 3.8 & 6.0 \\
\hline $\mathrm{pH}(\mathrm{KCl})$ & 5.0 & 5.2 & 5.8 & 5.0 & 5.7 \\
\hline$\Delta \mathrm{pH}$ & -1.6 & -1.3 & 0.8 & 1.2 & -0.3 \\
\hline $\mathrm{PCZ}$ & 3.4 & 3.9 & 6.6 & 6.2 & 5.4 \\
\hline $\mathrm{CO}\left(\mathrm{g} \mathrm{kg}^{-1}\right)$ & 4.1 & 10.4 & 4.1 & 7.0 & 4.0 \\
\hline $\mathrm{SiO}_{2}\left(\mathrm{~g} \mathrm{~kg}^{-1}\right)$ & 14.4 & 28.2 & 9.6 & 9.0 & 24.0 \\
\hline $\mathrm{Al}_{2} \mathrm{O}_{3}\left(\mathrm{~g} \mathrm{~kg}^{-1}\right)$ & 16.2 & 15.2 & 21.9 & 22.8 & 24.3 \\
\hline $\mathrm{Fe}_{2} \mathrm{O}_{3}\left(\mathrm{~g} \mathrm{~kg}^{-1}\right)$ & 13.3 & 16.2 & 22.3 & 25.8 & 18.2 \\
\hline $\mathrm{TiO}_{2}\left(\mathrm{~g} \mathrm{~kg}^{-1}\right)$ & 1.05 & 0.75 & 1.35 & 1.55 & 1.45 \\
\hline
\end{tabular}

P: soil profile; PVAe: Argissolo Vermelho-Amarelo Eutrófico típico; MTo: Chernossolo Argilúvico órtico típico; LVwf: Latossolo Vermelho Acriférrico típico; NVef: Nitossolo Vermelho eutroférrico típico; Bt: texture horizon B; Bw: B latossólico horizon. 
Table 2. Degree, size and type of structure determined in horizon B of soil samples

\begin{tabular}{lclll}
\hline & & & \multicolumn{2}{c}{ Structure } \\
\cline { 3 - 5 } Soil profile & Horizon & Degree & Size & Type \\
\hline P.1 - PVAe & Bt2 & High & Medium & Subangular and angular blocks \\
P.2 - MTo & Bt2 & High & Medium & Prismatic, angular blocks \\
P.3 - LVw & Bw2 & High & Very small & Granular \\
P.4 - LVwf & Bw2 & High & Very small & Granular \\
P.5 - NVef & Bt2 & Moderate & Small and mediaum & Prismatic, angular and subangular blocks \\
\hline
\end{tabular}

P: soil profile; PVAe: Argissolo Vermelho-Amarelo Eutrófico típico; MTo: Chernossolo Argilúvico órtico típico; LVwf: Latossolo Vermelho Acriférrico típico; NVef: Nitossolo Vermelho eutroférrico típico; Bt: textural horizon B; Bw: B latossólico horizon.

$10 \mathrm{~mL}$ of sodium hydroxide $(\mathrm{NaOH}) 1 \mathrm{~N}$; the solution was shaken on an orbital table for $3 \mathrm{~h}$; after shaking, the suspensions was sieved through $53 \mu$ mesh; the material retained in the sieve (sand fraction) was ovendried for $24 \mathrm{~h}$ at $105{ }^{\circ} \mathrm{C}$; the sieved material (silt + clay fraction) was filled in a test tube and completed with water to $500-\mathrm{mL}$. The time of silt sedimentation $(r=0.0001 \mathrm{~mm})$ was estimated based on Stokes' law, by equation 1:

$$
\mathrm{T}=\frac{9 * \mathrm{~h} * \eta}{2 *(\mathrm{Dp}-\mathrm{Dw}) * \mathrm{~g} * \mathrm{r}^{2}}
$$

where $\mathrm{T}=$ sedimentation time $(\mathrm{s}) ; \mathrm{h}=$ pipetting height (cm); $\eta=$ suspension water viscosity (poise); $\mathrm{Dp}=$ mean particle density $\left(\mathrm{kg} \mathrm{dm}^{-3}\right) ; \mathrm{Dw}=$ fluid density $\left(\mathrm{kg} \mathrm{dm}^{-3}\right)$; $\mathrm{g}=$ acceleration of gravity $\left(\mathrm{cm} \mathrm{s}^{-2}=980\right) ; \mathrm{r}=$ sediment particle radius $(\mathrm{mm})$.

The test tube solution was shaken ( $\pm 1 \mathrm{~min})$ and after the sedimentation time established by equation 1 , an aliquot of $10 \mathrm{~mL}$ was pipetted from a depth of $5 \mathrm{~cm}$; this aliquot was placed in a previously weighed melter and oven-dried for $24 \mathrm{~h}$ at $105^{\circ} \mathrm{C}$ and then the melter was weighed again, as well as the container with the sand. From the solution containing silt + clay the weight of $0.1 \mathrm{~mol} \mathrm{~L}{ }^{1} \mathrm{NaOH}$ was subtracted proportionally to the volume extracted (0.0008 g). The clay content was determined by equation 2 :

$$
\% \text { clay }=500 *\left(\mathrm{PSc}-\mathrm{P}_{\mathrm{NaOH}}\right)
$$

where $\%$ Clay = soil clay content $(\%) ; \mathrm{PSc}=$ dry weight of material contained in the melter $(\mathrm{g}) ; \mathrm{P}_{\mathrm{NaOH}}=$ weight of $\mathrm{NaOH}$ placed in the $10 \mathrm{~mL}$-pipetting solution.

The total sand was fractioned into coarse and fine sand; the material retained in each of the sieves was weighed and the percentage of the respective fractions was calculated by the "rule of three".

In treatment 2 (T.2), the same procedures were used as for T.1, adding $30 \mathrm{~g}$ of coarse sand to the $1 \mathrm{~N}$ $\mathrm{NaOH}$ solution; for treatment 3 (T.3) the procedures described for T.2 were used, adding $100 \mathrm{~mL}$ of $0.05 \mathrm{~N}$ hydrochloric acid $(\mathrm{HCl})$, instead of the $10 \mathrm{~mL}$ of $1 \mathrm{~N}$ $\mathrm{NaOH}$; for treatment 4 (T.4) the procedures for T.2 were repeated, but a pre-treatment was conducted to remove organic matter using $30 \%$ hydrogen peroxide (Embrapa, 1997); for treatment 5 (T.5) the T.2 procedures were applied after a pre-treatment for the removal of crystalline iron oxide and aluminum, using citrate-bicarbonate-dithionite (Jackson, 1958; Embrapa, 1997); for treatment 6 (T.6) the procedures were basically those for T.2, but applying the pretreatments used in T.4 and T.5; for treatment 7 (T.7) the procedures for T.2 were used, but after a pretreatment for the removal of the amorphous iron oxides, by the acid ammonium oxalate method (McKeague, 1978; Embrapa, 1997). For treatment 8 (T.8), the procedures for T.2 were used after a pretreatment with potassium phosphate; to perform this pre-treatment, the bottom of a PVC tube (approximate height $20 \mathrm{~cm}$, diameter $10 \mathrm{~cm}$ ) was closed with polystyrene, with a $1 \mathrm{~cm}$-diameter hole in the center filled with gauze to allow leaching; per $250 \mathrm{~g}$ soil, $50 \mathrm{~g}$ potassium phosphate was applied; this material was moistened twice a week to accelerate the reactions; the amount of water added each time was $15 \mathrm{~mL}$; the reaction period was eight weeks. For treatment 9 (T.9) the procedures for T.2 were used after a pre-treatment with calcium carbonate $\left(\mathrm{CaCO}_{3}\right)$; to perform this pretreatment, the bottom of a PVC tube (approximate height $20 \mathrm{~cm}$, diameter $10 \mathrm{~cm}$ ) was closed with polystyrene, with a $1 \mathrm{~cm}$-diameter hole in the center filled with gauze to allow leaching; per $250 \mathrm{~g}$ soil, $50 \mathrm{~g}$ potassium phosphate was applied; this material was moistened twice a week to accelerate the reactions; the amount of water added each time was $15 \mathrm{~mL}$; the reaction period was eight weeks. For treatment 10 (T.10) the procedures for T.2 were used, but the chemical dispersant was changed to $20 \mathrm{~g}$ of $\mathrm{NaOH}$ dissolved in $5 \mathrm{~L}$ of distilled water to which $50 \mathrm{~g}$ of sodium hexametaphosphate was added. This material was shaken by a magnetic shaker until the reagents were totally dissolved; $50 \mathrm{~mL}$ of the solution was used for $10 \mathrm{~g}$ of soil (Raij et al., 1996). For treatment 11 (T.11) the procedures for T.1 were used, changing the shaking method so that instead of the horizontal shaker the ultrasound method was applied using a Misonix apparatus, model XL2020TM, operating at $20 \mathrm{kHZ}$, on stage nine of the dial, at $80 \mathrm{~W}$; the soil- 
water ratio was 1:20, in compliance with Vitorino et al. (2001), and sonication time was $300 \mathrm{~s}$, corresponding, respectively, to the specific energy of $120 \mathrm{~J} \mathrm{~mL}^{-1}$ applied, calculated as proposed by Sá et al. (2000); for treatment 12 (T.12) the T.1 procedures were used, replacing $1 \mathrm{~N} \mathrm{NaOH}$ by $1 \mathrm{~N}$ lithium hydroxide $(\mathrm{LiOH})$; for treatment 13 (T.13) the T.2 procedures were applied, replacing $1 \mathrm{~N} \mathrm{NaOH}$ with $1 \mathrm{~N} \mathrm{LiOH}$.

The clay contents within the same soil and horizon were statistically analyzed by comparing the mean clay contents obtained in the dispersion of the samples in the 13 treatments, considering T.1 as standard treatment (due to its widespread use in most soil laboratories in Brazil), using Dunnett's test ( $p<0.05)$.

\section{RESULTS AND DISCUSSION}

Table 3 shows the mean clay contents of horizon $\mathrm{B}$ of the five soils analyzed, after undergoing the 13 treatments. The differences found by Dunnett's test in clay contents between the different treatments and standard treatment 1 (T.1) are shown in Table 4. Significant differences can be noted in clay contents of PVAe, NVef and LVwf, compared to treatment 1, which confirms the varying effects of the different treatments used for clay dispersion.

In the comparison, MTo was interesting when $\mathrm{LiOH}$ was used as a dispersant (T.12 and T.13), since no significant differences were observed compared to the reference treatment (T.1), indicating the predominance of $2: 1$ clay minerals, especially smectites. A likely reason is that in soils with this mineralogy, with a high CEC, electrostatic attraction between the negative electric charges of the different particles and bonding cations is mostly or solely responsible for particle bonding (Brady, 1989). Thus, the use of chemical dispersants that can neutralize the attraction electrostatic forces by replacing divalent ions with ions of great hydration radius becomes decisive for a satisfactory dispersion. The results show that for this purpose, $\mathrm{LiOH}$ was less efficient than all other dispersants in the different soil classes, and was totally inefficient in those with very low CEC.

Table 3. Mean clay contents determined in samples from the horizon B of five soils, applying 13 particle dispersion treatments

\begin{tabular}{|c|c|c|c|c|c|c|c|c|c|c|c|c|c|c|}
\hline Soil profile & Horizon & $\mathrm{T} 1$ & $\mathrm{~T} 2$ & T3 & $\mathrm{T} 4$ & T5 & T6 & $\mathbf{T 7}$ & T8 & T9 & T10 & T11 & $\mathrm{T} 12^{(1)}$ & $\mathrm{T} 13^{(1)}$ \\
\hline & & \multicolumn{13}{|c|}{$\mathrm{g} \mathrm{kg}^{-1}$} \\
\hline P.1-PVAe & $\mathrm{Bt}_{2}$ & 430 & 500 & 514 & 504 & 510 & 518 & 509 & 506 & 508 & 530 & 555 & 0 & 0 \\
\hline P.2-MTo & $\mathrm{Bt}_{2}$ & 615 & 650 & 680 & 665 & 659 & 675 & 674 & 665 & 667 & 676 & 690 & 605 & 624 \\
\hline P.3-LVwf & $\mathrm{Bw}_{2}$ & 451 & 530 & 590 & 530 & 548 & 558 & 570 & 546 & 544 & 519 & 569 & 0 & 0 \\
\hline P.4-LVwf & $\mathrm{Bw}_{2}$ & 531 & 610 & 665 & 625 & 650 & 669 & 649 & 630 & 630 & 606 & 667 & 0 & 0 \\
\hline P.5-NVef & $\mathrm{Bt}_{2}$ & 698 & 750 & 765 & 759 & 765 & 770 & 760 & 758 & 760 & 767 & 824 & 0 & 0 \\
\hline
\end{tabular}

(1) The "zero" value in the columns is justified as there was no clay dispersion in the soil samples of these treatments P: soil profile; PVAe: Argissolo Vermelho-Amarelo Eutrófico típico; MTo: Chernossolo Argilúvico órtico típico; LVwf: Latossolo Vermelho Acriférrico típico; NVef: Nitossolo Vermelho eutroférrico típico; Bt: textural horizon B; Bw: horizon B latossólico.

Table 4. Difference in the mean clay contents $\left(\mathrm{g} \mathrm{kg}^{-1}\right)$ between the dispersion treatments $(\mathrm{T})$ and the standard treatment (T1) in samples collected from horizon B of five soils

\begin{tabular}{|c|c|c|c|c|c|}
\hline $\begin{array}{c}\text { Treatment } \\
\text { T-T } 1\end{array}$ & $\begin{array}{c}\mathrm{P} .1-\mathrm{PVAe} \\
\mathrm{Bt}_{2}\end{array}$ & $\begin{array}{c}\text { P.2 - MTo } \\
\mathrm{Bt}_{2}\end{array}$ & $\begin{array}{c}\text { P.3 - LVwf } \\
\mathrm{Bw}_{2}\end{array}$ & $\begin{array}{c}\mathrm{P} .4-\mathrm{LVwf} \\
\mathrm{Bw}_{2}\end{array}$ & $\begin{array}{c}\text { P.5 - NVef } \\
\mathrm{Bt}_{2}\end{array}$ \\
\hline $2-1$ & $70^{*}$ & $35^{*}$ & $79 *$ & $79 *$ & $52^{*}$ \\
\hline $3-1$ & $84^{*}$ & $65^{*}$ & $139^{*}$ & $134^{*}$ & $67^{*}$ \\
\hline $4-1$ & $74^{*}$ & $50^{*}$ & $79 *$ & $94^{*}$ & $61^{*}$ \\
\hline $5-1$ & $80^{*}$ & $44^{*}$ & $97^{*}$ & $119^{*}$ & $67^{*}$ \\
\hline $6-1$ & $88^{*}$ & $60^{*}$ & $107^{*}$ & $138^{*}$ & $72^{*}$ \\
\hline $7-1$ & $79^{*}$ & $59^{*}$ & $119^{*}$ & $118^{*}$ & $62^{*}$ \\
\hline $8-1$ & $76^{*}$ & $50^{*}$ & $95^{*}$ & $99^{*}$ & $60^{*}$ \\
\hline $9-1$ & $78^{*}$ & $52^{*}$ & $93^{*}$ & $99^{*}$ & $62^{*}$ \\
\hline $10-1$ & $100^{*}$ & $61^{*}$ & $68^{*}$ & $75^{*}$ & $69^{*}$ \\
\hline $11-1$ & $125^{*}$ & $75^{*}$ & $118^{*}$ & $136^{*}$ & $126^{*}$ \\
\hline $12-1$ & $-430^{*}$ & $10 \mathrm{~ns}$ & $-451^{*}$ & $-531^{*}$ & $-698^{*}$ \\
\hline \multirow[t]{2}{*}{$13-1$} & $-430^{*}$ & $9 \mathrm{~ns}$ & $-451^{*}$ & $-531^{*}$ & $-698^{*}$ \\
\hline & $\mathrm{S}=35.4$ & $\mathrm{~S}=29.6$ & $\mathrm{~S}=30.6$ & $\mathrm{~S}=28.4$ & $\mathrm{~S}=24.2$ \\
\hline
\end{tabular}

P: soil profile; PVAe: Argissolo Vermelho-Amarelo Eutrófico típico; MTo: Chernossolo Argilúvico órtico típico; LVwf: Latossolo Vermelho Acriférrico típico; NVef: Nitossolo Vermelho eutroférrico típico; Bt: textural horizon B; Bw: horizon B latossólico.; ns,

*, respectively, not significant and significant at $5 \%$ by Dunnett's test; $\mathrm{S}=$ least significant difference. 
In horizon $\mathrm{B}$ of soils with predominantly negative charges in soil pH (MTo, NVef and PVAe), sodium hexametaphospathe was more efficient than the other dispersants, which can be explained by the joint action of ion $\mathrm{Na}^{+}$replacing divalent ions in the intermediary layers with the action of ion $\mathrm{H}^{+}$, displacing some monovalent ions (especially potassium) and facilitating greater hydration of the clay layers, thus eliminating the attraction forces between particles.

In the case of oxidic soils (LVwf), dispersion was mainly caused by the increase in the solution $\mathrm{pH}$, generating negative electric charges on oxide surfaces, through the reaction of the oxide ions with hydrogen of the functional groups, resulting in an increase in the number of charges and, consequently, in particle dispersion. For this reason, the sodium hydroxide $(\mathrm{NaOH})$ solution was more efficient in these soils.

$\mathrm{LiOH}$ was inefficient in the dispersion of low-CEC electropositive (P.3 and P.4) and electronegative soils (P.1 and P.5) and efficient in dispersing high-CEC electronegative soils (P.2). Although some authors (Baver, 1972) place LiOH first on the dispersant efficiency scale due to its small size, this can also be explained by a characteristic known as ionic potential, which is a measure of electronegativity (Mason, 1971; Birkeland, 1984). This feature is defined by the relation between ion charge and size, which provides it with a different ionizing power from that of $\mathrm{Na}^{+}$ and may justify its peculiar behavior as a dispersant in an aqueous medium.

Due to this characteristic, lithium $\left(\mathrm{Li}^{+}\right)$has a greater reactive power in aqueous medium than $\mathrm{Na}^{+}$ and in the absence of surfaces with a substantial amount of negative charges it is capable of precipitating as hydroxide, removing $\mathrm{OH}^{-}$from the water, which is what actually happens in low-CEC soils. $\mathrm{Na}^{+}$on the other hand, even in these soils, remains in solution, circulating among water molecules (more hydratable) and is attracted towards negative charges, created with the introduction of $\mathrm{OH}^{-}$ to the medium. In high-CEC soils, $\mathrm{Li}^{+}$takes on the function of replacing the divalent ions of the clay silicates, bringing about dispersion albeit less efficiently than sodium hexametaphosphate and $\mathrm{NaOH}$, for the very same reasons.

The use of coarse sand as an abrasive increased clay levels in all treatments in with chemical dispersant action. Similar results were found by Grohmann \& Raij (1977), Oliveira et al. (2002), Donagemma et al. (2003), Tavares-Filho \& Magalhães (2008) and Corá et al. (2009), among others. These authors stress that the differences found result from the abrasive action of the sand added to the soil material and/or to the shaking method, since in the case of slow shaking, the soil suspension is subjected to successive falls within the container, leading to aggregate attrition. Moreover, according to these authors, the main function of the use of sand as an abrasive is solely to undo the microaggregates strongly bonded by the cementing agents. These microaggregates form pseudo-silt, that is, particles the size of clay but because of insufficient chemical dispersion are quantified as silt, leading to underestimated clay fraction contents and, consequently, overestimated silt fraction contents in the soil.

The efficiency in the dispersion of lower CEC soils was greater (Table 3), and no efficiency was observed in soils where the chemical dispersant did not perform this function (treatments T.12 and T.13). In the latter, it can be concluded that the use of sand as an abrasive plays a role that is complementary to chemical dispersion. Yet, in the first case it is understood that the purpose of this action is essentially to facilitate the entry of water molecules (hydration) into the aggregates and the introduction of negative charges $\left(\mathrm{OH}^{-}\right)$to the hydroxyl oxide surfaces, inducing an increase of the clay double layer and dispersion.

In high and medium-CEC soils, with a small amount of $\mathrm{pH}$-dependent charges, the abrasive action is important and efficient to induce dispersion as it acts solely on medium-CEC soils. Therefore, the increase in dispersion observed can be attributed to the abrasive action of sand on the clay portion constituted by oxides (which is smaller) and the likely physical disintegration of larger particles.

Dispersion based on ultrasound produced better results than treatments T.1 and T.2 in all samples. This treatment proved more efficient than the others, considering the total amount of determined clay, showing that it undoubtedly had a much higher disaggregating power. The behavior for different soil categories followed the same trend when compared to the use of coarse sand as an abrasive, differing only with regard to the determined clay, which was higher in this case.

The results of treatments for the elimination of free iron oxides had a positive influence in terms of improving dispersion, particularly in the case of very red soils, characterizing the presence of hematite $\left(\mathrm{F}_{2} \mathrm{O}_{3}\right)$. Treatments T.5, T.6 and T.7 were more efficient (i.e., higher total clay content detected) than in treatment T.2, here the control treatment, as the use of coarse sand as an abrasive did not influence the comparisons. Among the soils, the main responses were observed in those derived from basalt (P.4 and P.5), with high total iron content, which was clearly responsible for a greater presence of free iron.

Aside from using $\mathrm{NaOH}$ as a dispersant which, among other functions, induces a $\mathrm{pH}$ increase in the soil solution, this study also applied additional pretreatments such as the addition of $\mathrm{PO}_{4}=$ with high ionic potential (Mason, 1971; Birkeland, 1984; Essington, 2004). $\mathrm{PO}_{4}{ }^{=}$was used to introduce negative charges to the oxidic clays (said to have a hydroxyl surface) and the use of specific treatments $\left(\mathrm{CaCO}_{3}\right)$ to increase soil $\mathrm{pH}$. In both cases, the ultimate purpose was to increase soil CEC and increase particle dispersion, especially in the Oxisols. 
$\mathrm{NaOH}$ addition was efficient in all soils, proving that $\mathrm{pH}$ increase with the introduction of $\mathrm{NaOH}$ ions produced negative charges on the hydroxyl surfaces that predominate in Oxisols and/or displaced cations adsorbed in the clay minerals that predominate in the other soils, by $\mathrm{Na}^{+}$. However, the efficiency of $\mathrm{PO}_{4}=$ addition was not the same, which in principle can be explained by the nature of the charges present in each soil category.

The results confirm that $\mathrm{PO}_{4}=$ addition improves the clay dispersion capacity in Oxisols (P.3 and P.4), followed by Mollisol (P.2) and Alfisols (P.1 and P.5). In the case of oxidic soils (P.3 and P.4), considering that the total amount of charges is predominantly positive, the efficacy of $\mathrm{PO}_{4}{ }^{=}$was rather significant. In treatment P.2 (Mollisol), the amount of $\mathrm{pH}$ dependent positive charges, although detectable, is small compared to the total amount of charges and the significance of the action of phosphate addition in percentage is reduced.

In kaolinitic soils (P.1 and P.5), the action of $\mathrm{PO}_{4}=$ was the least significant of all. According to Brady (1989), the total amount of electric charges of kaolinite is much lower than that of montmorillonite and a little more than half of them is $\mathrm{pH}$-dependent. At a low $\mathrm{pH}$, these charges would therefore become positive, thus reducing the action of $\mathrm{PO}_{4}=$ addition in percentage terms in the clay fraction of kaolinitic soils, compared to the other soils.

\section{CONCLUSIONS}

1. Differentiated treatments are required to determine clay, taking the distinct mineralogy of soil classes into account.

2. Field-determined data of soil structure and consistence are direct indicators of soil mineralogy.

3. Lithium hydroxide is not efficient in the dispersion of low-CEC electropositive soils and is very efficient in dispersing high-CEC electronegative soils.

4. The use of coarse sand as an abrasive increases the clay content in all treatments where dispersion occurs, for all soils, with and without the use of a chemical dispersant.

5 . The efficacy of coarse sand is not the same for all soil classes.

\section{ACKNOWLEDGEMENTS}

The authors wish to thank Solocria Laboratório Agropecuário for financial support.

\section{LITERATURE CITED}

BARRETO, W. Eletroquímica de solos tropicais de carga variável: capacidade da dupla camada elétrica. Rio de Janeiro, Universidade Federal Rural do Rio de Janeiro, 1986. 273p. (Tese de Doutorado)

BAVER, L.D.; GARDNER, W.H. \& GARDNER, W.R. Soil physics. 4.ed. New York, John Wiley \& Sons, 1972. 498p.

BIRKELAND, P.W. Soil and geomorphology. New York, Oxford University Press, 1984. 372p.

BRADY, N.C. Natureza e propriedades dos solos. 7.ed. Rio de Janeiro, Freitas Bastos, 1989. 898p.

CARVALHO, M.A. Eficiência de dispersantes na análise textural de materiais de solos com horizonte B latossólico e B textural. Lavras, Escola Superior de Agricultura de Lavras, 1985. 79p. (Tese de Mestrado)

CORÁ, J.E.; FERNANDES, C.; BERALDO, J.M.G. \& MARCELO, A.V. Adição de areia para dispersão de solos na análise granulométrica. R. Bras. Ci. Solo, 33:255-262, 2009.

DAY, P.R. Particle fractionation and particle-size analysis. In: BLACK, C.A., ed. Methods of soil analysis: Physical and mineralogical properties including statistics of measurement and sampling. Madison, American Society of Agronomy, 1965. Part 1. p.545-567.

DONAGEMMA, G.K.; RUIZ, H.A.; FONTES, M.P.F.; KER, J.C. \& SCHAEFER, C.E.G.R. Dispersão de Latossolos em resposta à utilização de pré-tratamentos na análise textural. R. Bras. Ci. Solo, 27:765-772, 2003.

EMPRESA BRASILEIRA DE PESQUISA AGROPECUÁRIA EMBRAPA. Centro Nacional de Pesquisa de Solos. Manual de métodos de análise de solo. 2.ed. Brasília, Embrapa Produção de Informação; Rio de Janeiro, Embrapa Solos, 1997. 212p.

EMPRESA BRASILEIRA DE PESQUISA AGROPECUÁRIA EMBRAPA. Centro Nacional de Pesquisa de Solos. Sistema brasileiro de classificação de solos. 2.ed. Brasília, Embrapa Produção de Informação; Rio de Janeiro, Embrapa Solos, 2006. 306p.

ESSINGTON, M.E. Soil and water chemistry: An integrative approach. Boca Raton, CRC Press, 2004. 534p.

GEE, G.W. \& BAUDER, J.W. Particle-size analysis. In: KLUTE, A., ed. Methods of soil analysis: Physical and mineralogical methods. 2.ed. Madison, American Society of Agronomy, 1986. Part 1. p.383-411.

GENRICH, D.A. \& BREMNER, J.M. A reevaluation of the ultrasonic vibration method of dispersing soils. Soil Sci. Soc. Am. J. Proc., 36:944-947, 1972.

GROHMANN, F. A vibração ultrassônica na dispersão de Latossolos argilosos. In: CONGRESSO BRASILEIRO DE CIÊNCIA DO SOLO, 15., Campinas, 1975. Anais... Campinas, Sociedade Brasileira de Ciência do Solo, 1975. p.27-30. 
GROHMANN, F. \& RAIJ, B.van. Dispersão mecânica e prétratamento para análise granulométrica de Latossolos argilosos. R. Bras. Ci. Solo, 1:52-53, 1977.

JACKSON, M.L. Soil chemical analysis. Englewood Cliffs, Prentice-Hall, 1958. 498p.

MASON, B.H. Princípios de geoquímica. São Paulo, Polígono/ USP, 1971. 403p.

McKEAGUE, J.A. Manual on soil sampling and methods of analysis. 2.ed. Ottawa, Canadian Society of the Soil Science, 1978. 212p.

MEDINA, H.P. \& GROHMANN, F. Contribuição ao estudo da análise granulométrica do solo. In: CONGRESSO BRASILEIRO DE CIÊNCIA DO SOLO, 6., Salvador, 1957. Anais... Rio de Janeiro, Sociedade Brasileira de Ciência do Solo, 1962. p.29-38.

MENK, J.R. \& OLIVEIRA, J.B. Estudo comparativo da influência de agentes dispersantes e de pré-tratamentos na análise granulométrica de solos. In: CONGRESSO BRASILEIRO DE CIÊNCIA DO SOLO, 14., Santa Maria, 1973. Anais... Rio de Janeiro, Sociedade Brasileira de Ciência do Solo, 1974. p.104-121.

OLIVEIRA, G.C.; DIAS JÚNIOR, M.S.; VITORINO, A.C.T.; FERREIRA, M.M.; SÁ, M.A.C. \& LIMA, J.M. Agitador horizontal de movimento helicoidal na dispersão mecânica de amostras de três Latossolos do Sul e Campos das Vertentes de Minas Gerais. Ci. Agrotec., 26:881-887, 2002.
OLIVEIRA, V. A., coord. Manual técnico de pedologia. 2.ed. Rio de Janeiro, IBGE, 2007. 300p. (IBGE. Manuais Técnicos em Geociências, 4)

RAIJ, B.van; CANTARELLA, H.; QUAGGIO, J.A. \& FURLANI, A.M.C., eds. Recomendações de adubação e calagem para o Estado de São Paulo. 2.ed. Campinas, Instituto Agronômico \& Fundação IAC, 1996. 285p. (Boletim Técnico, 100).

SÁ, M.A.C.; LIMA, J.M. \& LAGE, G. Procedimento padrão para medida da potência liberada pelo aparelho de ultrasom. Ci. Agrotec., 24:300-306, 2000.

SANTANA, D.P. Estudo de solos do Triângulo Mineiro e de Viçosa: I. Mineralogia, II. Adsorção de fosfatos. Viçosa, MG, Universidade Federal de Viçosa, 1973. 56p. (Tese de Doutorado)

TAVARES-FILHO, J. \& MAGALHÃES, S.F. Dispersão de amostras de Latossolo Vermelho Eutroférrico influenciadas por pré-tratamento para oxidação da matéria orgânica e pelo tipo de agitação mecânica. R. Bras. Ci. Solo, 32:1429-1435, 2008.

VITORINO, A.C.T.; FERREIRA, M.M.; OLIVEIRA, G.C.; DIAS JÚNIOR, M.S.; SÁ, M.A.C.; LIMA, J.M. \& CURI, N. Níveis de energia ultra-sônica na dispersão de argila de solos da região de Lavras (MG). Ci. Agrotec., 25:1330-1336, 2001. 